\title{
ASSESSMENT OF THE INFLUENCE OF EXPANDED HEMODIALYSIS ON THE RATE OF REMOVAL OF MIDDLE MOLECULAR WEIGHT UREMIC TOXINS
}

\author{
Marko Nenadovicl, Aleksandra Nikolic², Milica Kostovic ${ }^{3}$, Branislava Draskovic 3 , Milena Jovanovic ${ }^{3}$, \\ Tomislav Nikolic1,3, Dejan Petrovic ${ }^{1,3}$ \\ ${ }^{1}$ University of Kragujevac, Faculty of Medical Sciences, Kragujevac, Serbia \\ ${ }^{2}$ University Clinical Centre Kragujevac, Clinic for Internal Medicine, Kragujevac, Serbia \\ ${ }_{3}^{3}$ University Clinical Centre Kragujevac, Clinic for Urology, Nephrology and Dialysis, Kragujevac, Serbia
}

\section{PROCENA UTICAJA PROŠIRENE HEMODIJALIZE NA STEPEN UKLANJANJA UREMIJSKIH TOKSINA SREDNJE MOLEKULSKE MASE}

\author{
Marko Nenadovićl, Aleksandra Nikolić2, Milica Kostović3 , Branislava Drašković3, Milena Jovanović3 \\ Tomislav Nikolićl,3, Dejan Petrovićl,3 \\ 1Univerzitet u Kragujevcu, Fakultet medicinskih nauka, Kragujevac \\ ${ }^{2}$ Univerzitetski klinički centar Kragujevac, Klinika za internu medicinu, Kragujevac \\ ${ }^{3}$ Univerzitetski klinički centar Kragujevac, Klinika za urologiju, nefrologiju i dijalizu, Kragujevac
}

\section{ABSTRACT}

Objective. The aim of this study was to examine the effect of expanded hemodialysis on the degree of $\beta_{2}$-microglobulin removal.

Methods. Sixteen patients treated with extended MCO hemodialysis were examined. The main parameter for assessing the efficiency of removal of uremic toxins of middle molecular weight is the concentration of $\beta_{2}$-microglobulin in the serum before and after a single session of extended MCO hemodialysis. The following were used for statistical analysis: Kolmogorov-Smirnov test, Student's T test for bound samples and Wilcoxon test.

Results. Extended MCO hemodialysis effectively removes uremic toxins of middle molecular weight. The reduction index of $\beta_{2}$-microglobulin during a single session of extended MCO hemodialysis is $70.60 \pm 5.88 \%$. The average loss of albumin during a single session of extended MCO hemodialysis is $1.88 \pm 1.02 \mathrm{~g} / 4 \mathrm{~h}$, and the index of albumin reduction is $4.94 \pm 2.49 \%$.

Conclusion. Extended MCO hemodialysis effectively removes $\beta_{2}$-microglobulin. The $\beta_{2}$-microglobulin reduction index is $\sim 71 \%$ and the albumin loss is less than $4.0 \mathrm{~g} / 4 \mathrm{~h}$. This dialysis modality prevents the development of amyloidosis, atherosclerosis and atherosclerotic cardiovascular diseases in the population of patients treated with regular hemodialysis.

Key words: renal dialysis; uremia; beta 2-microglobulin

\section{INTRODUCTION}

Cardiovascular diseases are the leading cause of death in patients treated with regular hemodialysis $(1,2)$. Uremic toxins play a significant role in the development of accelerated atherosclerosis and cardiovascular disease in this patient population. According to the recommendations of the EUTox (European Union Toxin Working Group), uremic toxins can be divided into three groups. The first

\section{SAŽETAK}

Cilj. Rad je imao za cilj da ispita uticaj proširene hemodijalize na stepen uklanjanja $\beta_{2}$-mikroglobulina.

Metode. Ispitano je 16 bolesnika koji se leče proširenom MCO hemodijalizom. Glavni parametar za procenu efikasnosti uklanjanja uremijskih toksina srednje molekulske mase bila je koncentracija $\beta_{2}$-mikroglobulina u serumu pre $i$ nakon pojedinačne sesije proširene MCO hemodijalize. Za statističku analizu korišćeni su Kolmogorov-Smirnov test, Studentov t-test za vezane uzorke i Vilkoksonov test.

Rezultati. Proširena MCO hemodijaliza efikasno uklanja uremijske toksine srednje molekulske mase. Indeks redukcije $\beta_{2}$-mikroglobulina u toku pojedinačne sesije proširene MCO hemodijalize iznosi 70,60 \pm 5,88\%. Prosečan gubitak albumina u toku pojedinačne sesije proširene MCO hemodijalize iznosi 1,88 $\pm 1,02 \mathrm{~g} / 4 \mathrm{~h}$, a indeks redukcije albumina 4,94 $\pm 2,49 \%$.

Zaključak. Proširena MCO hemodijaliza efikasno uklanja $\beta_{2}$-mikroglobulin. Indeks redukcije $\beta_{2-}$ mikroglobulina iznosi $\sim 71 \%$, a gubitak albumina je manji od 4,0 g/ 4 h. Ovaj modalitet dijalize sprečava razvoj amiloidoze, ateroskleroze $i$ aterosklerotskih kardiovaskularnih bolesti u populaciji bolesnika koji se leče redovnom hemodijalizom.

Ključne reči: bubrežna dijaliza; uremija; beta 2mikroglobulin

group consists of uremic toxins of low molecular weight $(\mathrm{MW}<500 \mathrm{Da})$. These toxins are soluble in water and are effectively removed by standard high-flux hemodialysis.

The second group consists of uremic toxins that bind in a high percentage to plasma proteins (degree of binding to plasma proteins $>90 \%$ ). They are mainly of low molecular weight $(\mathrm{MW}<500 \mathrm{Da})$ and are efficiently removed by hemodialysis with membranes that have the ability to adsorb. Middle molecular weight uremic toxins 
(MW $=0.5-60 \mathrm{kDa}$ ) belong to the third group of uremic toxins. These uremic toxins are effectively removed by postdilution online hemodiafiltration and extended hemodialysis (ED) (3).

Middle molecular weight uremic toxins include proinflammatory cytokines (interleukin-1 $\beta$, interleukin-6, interleukin-18, tumor necrosis factor alpha TNF $\alpha$ ), proteins (pentraxin-3, YKL-40) and adipokines (leptin) (3). Proinflammatory cytokines and proteins play a significant role in the development of microinflammation, while leptin plays a significant role in the development of malnutrition in patients treated with regular hemodialysis (3). Microinflammation, malnutrition and oxidative stress are significant non-traditional risk factors, resulting in the development of accelerated atherosclerosis (atherosclerotic cardiovascular disease), hemodialysis-related amyloidosis, erythropoietin resistance and anemia (3-10).

Hemodialysis membranes play the key role in the process of hemodialysis and hemodiafiltration. They can be natural or artificial (synthetic). Natural membranes are cellulose derivatives, they are "low-flux", they are less biocompatible compared to synthetic membranes and they have a small clearance of medium molecular weight uremic toxins. Synthetic membranes (polysufon, polyamide, polyacrylonitrile) are highly biocompatible "high-flux" membranes, which have a good clearance of middle molecular weight uremic toxins $(11,12)$.

In clinical practice, measurement of the concentration of $\beta_{2}$-microglobulin and albumin in the serum, before and after the session, is used to assess the efficiency of removal of uremic toxins of middle molecular weight during a single session of extended hemodialysis (MCO hemodialysis). Based on the concentration of $\beta_{2}$ microglobulin in the serum before and after the session of extended MCO hemodialysis, the reduction index for $\beta_{2}-$ microglobulin - RR (Reduction Ratio) is calculated. It is calculated by the formula: $R R(\%)=[1-($ Cpost / Cpre $)] x$ 100, where: Cpre - serum $\beta_{2}$-microglobulin concentration before the extended MCO hemodialysis session $(\mathrm{mg} / \mathrm{L})$, Cpost - $\beta_{2}$-serum microglobulin after an extended MCO hemodialysis session $(\mathrm{mg} / \mathrm{L})(12,13)$.

During a high-flux hemodialysis session, the reduction index for $\beta_{2}$-microglobulin is $50-60 \%$, for $\mathrm{MCO}$ hemodialysis (medium cut-off dialysis membrane) $70 \%$, and for high-volume postdilution online hemodiafiltration $80-85 \%$ ( $R R \geq 80 \%)$. According to the recommendations of the JSDT (Japanese Society for Dialysis Therapy), the predialysis concentration of $\beta_{2}$-microglobulin in the serum should be less than $30 \mathrm{mg} / \mathrm{L}$ and less than $25 \mathrm{mg} / \mathrm{L}$, respectively $(13,14)$.

Extended MCO hemodialysis effectively removes uremic toxins of middle molecular weight by diffusion process ("medium cut-off" hemodialysis membrane) and internal filtration process (high internal filtration is due to a combination of hydraulic membrane permeability and reduced internal capillary fiber diameter) $(13,14)$. High internal filtration and increased MCO membrane sieving capacity increase the clearance of uremic toxins of middle molecular weight. With the MCO membrane of $1.7 \mathrm{~m}^{2}$ (Theranova ${ }^{\circledR} 400$ ), the internal filtration is in the range of $20-25 \mathrm{~mL} / \mathrm{min}$, and with the MCO membrane of $2.0 \mathrm{~m}^{2}$ (Theranova ${ }^{\circledR} 500$ ), the internal filtration is in the range of 30- $50 \mathrm{~mL} / \mathrm{min}$. During an extended MCO hemodialysis session, less than $4.0 \mathrm{~g}$ of albumin $(\leq 4.0 \mathrm{~g} / 4 \mathrm{~h})$ is lost, which is of great importance in order to prevent the development of malnutrition (14).

Depending on the clearance of $\beta_{2}$-microglobulin and the sieving coefficient for albumin - SC (Sieving Coefficient), we distinguish four types of membranes for hemodialysis. In type 1 , the clearance of $\beta_{2}$-microglobulin is less than $70 \mathrm{~mL} / \mathrm{min}$, and in type $2 \geq 70 \mathrm{~mL} / \mathrm{min}$. Depending on the screening coefficient for albumin, type 1 has two subtypes, subtype 1a (SC for albumin $<0.03$ ) and subtype $1 \mathrm{~b}$ (SC for albumin $\geq 0.03$ ). In type $2 \mathrm{a}$, the sieving coefficient for albumin is less than 0.03 , and in type $2 b \geq 0.03$ (14).

The main characteristics of dialyzers used for postdilution online hemodiafiltration are: high ultrafiltration coefficient (Kuf > $40 \mathrm{~mL} / \mathrm{h} \mathrm{x} \mathrm{mmHg}$ ), sieving coefficient for $\beta_{2}$-microglobulin greater than 0.60 , sieving coefficient for albumin less than 0.01 (albumin loss per session less than $4.0 \mathrm{~g}$ ), capillary density greater than 11.000 allows the flow of dialysis solution $-\mathrm{Qd}=$ $400-500 \mathrm{~mL} / \mathrm{min}$, inner diameter of the dialyzer capillaries greater than $200 \mu \mathrm{m}$, sterilization without ethylene oxide, the absence of bisphenol A - BPA (bisphenol A) and good biocompatibility. Dialyzers with dialysis membranes with an area of $\geq 2.0 \mathrm{~m}^{2}$ should be used to optimize the filtration fraction in postdilution online hemodiafiltration $(15,16)$.

\section{PATIENTS AND METHODS}

The study examined 16 patients treated with regular extended hemodialysis (HDx) at the Center for Nephrology and Dialysis of the Clinical Center Kragujevac. The study was conducted in compliance with the Helsinki Declaration on Medical Research, obtained the consent of the Ethics Committee of the Clinical Center Kragujevac (Decision of the Ethics Committee No. 01-20765) and the consent of patients.

The patients were treated with regular extended hemodialysis (MCO hemodialysis), three times a week for 4 hours (12 hours per week), for a period of three months, MCO "medium cut-off" biocompatible membrane (Theranova ${ }^{\circledR} 500, \alpha$ Polysulfone Pro, surface $2.0 \mathrm{~m}^{2}$, 
steam sterilization, sieving coefficient for $\beta_{2}$ microglobulin $-\mathrm{SC}=1.0$, sieving coefficient for albumin $-\mathrm{SC}<0.008$, ultrafiltration coefficient - Kuf $=59$ $\mathrm{mL} / \mathrm{h} / \mathrm{mmHg}$, manufacturer Baxter), on machines with controlled ultrafiltration type Fresenius 5008S, Gambro Artis and BBraun, with average blood flow rate - $\mathrm{Qb}=$ $230.00 \pm 30.55 \mathrm{~mL} / \mathrm{min}$ and average dialysate flow rate $\mathrm{Qd}=500.00 \pm 0.00 \mathrm{~mL} / \mathrm{min}$.

A standard ultrapure hemodialysis solution (number of bacterial colonies $<0.1 \mathrm{CFU} / \mathrm{mL}$, endotoxin concentration - $\mathrm{E}<0.03 \mathrm{EU} / \mathrm{mL}$ ) was used, with a calcium concentration of $1.75 \mathrm{mmol} / \mathrm{L}$ (PGS21), $1.50 \mathrm{mmol} / \mathrm{L}$ (PGS25) and $1.25 \mathrm{mmol} / \mathrm{L}$ (PGS27). The concentration of sodium $\mathrm{Na}^{+}$in the hemodialysis solution was $140 \mathrm{mmol} / \mathrm{L}$, the concentration of bicarbonate was $35 \mathrm{mmol} / \mathrm{L}$, and the concentration of $\mathrm{K}^{+}$was $2.0 \mathrm{mmol} / \mathrm{L}$. Unfractionated heparin was used for anticoagulation of extracorporeal circulation. The average monthly dose of unfractionated heparin was $4578.12 \pm 218.30 \mathrm{IU}$. All patients were treated with agents that stimulate erythropoiesis (shortacting: epoetin- $\alpha$, epoetin- $\beta$; long-acting: darbepoetin- $\alpha$ ). The study did not include patients with active infection (mean leukocyte count was $6.25 \pm 2.00 \times 10^{9} / \mathrm{L}$ ), proven active bleeding, uncontrolled malignancies, or patients treated with immunosuppressive drugs.

In order to assess the degree of removal of uremic toxins of medium molecular weight and the degree of protein loss during a single session of extended hemodialysis (MCO hemodialysis), the concentration of $\beta_{2}$-microglobulin and albumin in the serum was examined, before and after the hemodialysis session with MCO membrane (Theranova ${ }^{\circledR}$ 500). Based on the measured concentration of $\beta_{2}$-microglobulin, the reduction index RR (Reduction Ratio) was calculated using the formula: RR $(\%)=[1-($ Cpost/Cpre $)] \times 100$, where: Cpre concentration of $\beta_{2}$-microglobulin in serum before extended hemodialysis session ( $\mathrm{mg} / \mathrm{L})$, Cpost - serum $\beta_{2}-$ microglobulin concentration after extended hemodialysis session $(\mathrm{mg} / \mathrm{L})$. Based on the measured albumin concentration, the reduction index - RR (Reduction Ratio) was calculated using the formula: RR $(\%)=[1-($ Cpost $/$ Cpre)] x 100, where: Cpre - serum albumin concentration before the session was extended hemodialysis (g/L), Cpost - serum albumin concentration after extended hemodialysis session $(\mathrm{g} / \mathrm{L})$.

A blood sample for laboratory analysis was taken before the start and after the end of the average weekly single session of extended hemodialysis, before heparin administration. Routine laboratory analyzes were determined by standard laboratory tests and were calculated as the average value of three measurements over three consecutive months.
Serum albumin concentration was determined by turbidimetric method, on a Beckman Coulter AU680. In patients treated with regular hemodialysis, hypoalbuminemia is defined as a serum albumin concentration of less than $35 \mathrm{~g} / \mathrm{L}$.

Serum albumin concentration after an extended hemodialysis is calculated from the equation: Albumin post $=$ Calb post $/\{1+[(\mathrm{UF}) / 0.2 \times(\mathrm{BWpre}-\mathrm{UF})]\}$, where: UF $=$ BWpre - BWpost. BWpost - body weight of patients before dialysis $(\mathrm{kg})$, BWpost - body weight of patients after dialysis $(\mathrm{kg})$. Calb - serum albumin concentration $(\mathrm{g} / \mathrm{L}), \mathrm{UF}$ - netoultrafiltration flow rate $(\mathrm{L} / 4 \mathrm{~h})$.

Serum $\beta_{2}$-microglobulin concentration was determined by turbidimetric method, on a Beckman Coulter AU680. In patients treated with regular hemodialysis, the predialysis serum $\beta_{2}$-microglobulin concentration should be less than $25 \mathrm{mg} / \mathrm{L}$.

Serum ferritin concentration was determined by turbidimetric method, on a Beckman Coulter AU680. In patients treated with regular hemodialysis, the normal serum ferritin concentration is $100-500 \mathrm{ng} / \mathrm{mL}$.

Serum CRP concentration was determined by the turbidimetric method, on an Olympus AU680 instrument, and was calculated as the average of three measurements over three consecutive months. The normal serum CRP concentration is $\leq 5 \mathrm{mg} / \mathrm{L}$. Microinflammation is defined as a serum CRP concentration greater than $5 \mathrm{mg} / \mathrm{L}$.

The concentration of vitamin $\mathrm{D}$ in the serum was determined by the method of electrochemiluminescence, on the Cobas e 411 apparatus. The normal concentration of vitamin $\mathrm{D}$ in the serum is $20-40 \mathrm{ng} / \mathrm{mL}$. In patients treated with regular hemodialysis, the normal vitamin $\mathrm{D}$ concentration is $\geq 30 \mathrm{ng} / \mathrm{mL}(30-80 \mathrm{ng} / \mathrm{mL})$. Severe deficiency is defined as a vitamin $\mathrm{D}$ concentration $<10$ $\mathrm{ng} / \mathrm{mL}$, vitamin $\mathrm{D}$ deficiency exists if the concentration is $10-20 \mathrm{ng} / \mathrm{mL}$, and insufficiency is defined as a serum vitamin D concentration of $20-30 \mathrm{ng} / \mathrm{mL}$.

Serum intact parathyroid hormone concentration was determined by immunoradiometric method (IRMA) on a WALLAC WIZARD 1470 gamma counter. Normal serum intact parathyroid hormone concentration is 11.8-64.5 $\mathrm{pg} / \mathrm{mL}$. In patients treated with regular hemodialysis, the upper normal limit is $300 \mathrm{pg} / \mathrm{mL}$.

Prealbumin and transferrin were detemined on Abbott Architect analyzer using methods as follows: prealbumin and transferrin - immunoturbidimetric method. In patients treated with regular hemodialysis, the normal serum prealbumin concentration is $\geq 0.30 \mathrm{~g} / \mathrm{L}$ ( $\geq 30 \mathrm{mg} / \mathrm{dL}$ ).

Normalized degree of protein degradation - nPCR was calculated based on the formula: $\mathrm{nPCR}=(\mathrm{PCR} \times 0.58) / \mathrm{Vd}$, where: PCR - degree of protein degradation, and $\mathrm{Vd}-$ fluid volume in the body. PCR is calculated by the formula: $\mathrm{PCR}=[(9.35 \times \mathrm{G})+(0.29 \times \mathrm{Vd})]$, where: $\mathrm{G}-$ the degree 
of urea formation, and $\mathrm{Vd}$ - the volume of fluid in the body.

The degree of urea production is calculated by the formula

$-\mathrm{G}=[(\mathrm{C} 1-\mathrm{C} 2) / \mathrm{Id}] \times \mathrm{Vd}$, where: $\mathrm{C} 1$ - serum urea concentration before dialysis $(\mathrm{mmol} / \mathrm{L}), \mathrm{C} 2$ - serum urea concentration after dialysis $(\mathrm{mmol} / \mathrm{L}), \mathrm{Id}$ - time between two dialyzes (h). The volume of fluid in the body is calculated by the formula: $\mathrm{Vd}=0.58 \times \mathrm{DW}$, where $\mathrm{DW}-$ dry body weight of the patient after hemodialysis $(\mathrm{kg})$.

Table 1. Dialyzer characteristics

\begin{tabular}{|l|c|c|}
\hline Characteristics & Theranova $^{\circledR} 400$ & Theranova $^{\circledR} 500$ \\
\hline Membrane & Polyarylethersulfone & Polyarylethersulfone \\
\hline Manufacturer & Baxter, USA & Baxter, USA \\
\hline Surface & $1.7 \mathrm{~m}^{2}$ & $2.0 \mathrm{~m}^{2}$ \\
\hline Kuf $(\mathrm{mL} / \mathrm{h}$ x mmHg) & 48 & 39 \\
\hline Wall thickness $(\mu \mathrm{m})$ & 35 & 180 \\
\hline Inner diameter $(\mu \mathrm{m})$ & 180 & 1.0 \\
\hline Beta-2-microglobulin SC & 1.0 & 0.9 \\
\hline Myoglobin SC & 0.9 & 0.008 \\
\hline Albumin SC & 0.008 & Steam \\
\hline Sterilization & Steam & \\
\hline
\end{tabular}

Kuf - ultrafiltration coefficient, SC - sieving coefficient

Table 2. General patient data

\begin{tabular}{|c|c|c|}
\hline \multirow{2}{*}{\multicolumn{2}{|c|}{ Variable }} & Value \\
\hline & & $\mathrm{Xsr} \pm \mathrm{SD}$ \\
\hline \multicolumn{2}{|c|}{ Number $(\mathrm{N})$} & 16 \\
\hline \multicolumn{2}{|c|}{ Gender $(\mathrm{m} / \mathrm{f}, \%)$} & $12 / 4(75.00 / 25.00)$ \\
\hline \multicolumn{2}{|c|}{ Age (years) } & $60.38 \pm 9.81$ \\
\hline \multicolumn{2}{|c|}{ Length of dialysis treatment (years) } & $3.97 \pm 3.60$ \\
\hline \multicolumn{2}{|r|}{ Body mass index - BMI $\left(\mathrm{kg} / \mathrm{m}^{2}\right)$} & $27.31 \pm 8.05$ \\
\hline \multicolumn{2}{|r|}{ Systolic arterial blood pressure - SBP $(\mathrm{mmHg})$} & $125.00 \pm 12.11$ \\
\hline \multicolumn{2}{|r|}{ Diastolic arterial blood pressure - DBP $(\mathrm{mmHg})$} & $74.38 \pm 7.27$ \\
\hline \multicolumn{2}{|r|}{ Mean arterial blood pressure - MAP $(\mathrm{mmHg})$} & $91.25 \pm 8.42$ \\
\hline \multicolumn{2}{|r|}{ Dry body weight of the patient $-\mathrm{W}(\mathrm{kg})$} & $83.00 \pm 29.80$ \\
\hline \multicolumn{2}{|r|}{ Interdialysis yield in BM - IDWG (kg) } & $2.97 \pm 0.90$ \\
\hline \multicolumn{2}{|r|}{ Percentage of interdialysis yield in BM - IDWG (\%) } & $3.74 \pm 1.18$ \\
\hline \multicolumn{2}{|r|}{ Ultrafiltration rate $-\mathrm{UF}(\mathrm{mL} / \mathrm{h})$} & $750.00 \pm 223.60$ \\
\hline \multicolumn{2}{|r|}{ Ultrafiltration rate - UFR $(\mathrm{mL} / \mathrm{kg} / \mathrm{h})$} & $9.45 \pm 2.92$ \\
\hline \multicolumn{2}{|r|}{ Blood flow through the vascular approach - Qavf (mL/min) } & $837.50 \pm 503.94$ \\
\hline \multicolumn{2}{|r|}{ Hemodialysis adequacy index $-\mathrm{Kt} / \mathrm{V}$} & $1.05 \pm 0.18$ \\
\hline \multicolumn{2}{|r|}{ Single pool hemodialysis adequacy index $-\mathrm{spKt} / \mathrm{V}$} & $1.25 \pm 0.30$ \\
\hline \multicolumn{2}{|r|}{ Degree of urea reduction - URR (\%) } & $64.45 \pm 6.25$ \\
\hline \multirow{6}{*}{ 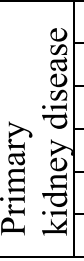 } & Glomerulonephritis chronica (N, \%) & $1(6.25)$ \\
\hline & Nephropathia hypertensiva (N, \%) & $1(6.25)$ \\
\hline & Nephropathia diabetica $(\mathrm{N}, \%)$ & $5(31.25)$ \\
\hline & Nephropathia obstructiva (N, \%) & $1(6.25)$ \\
\hline & Nephropathia chronica $(\mathrm{N}, \%)$ & $5(31.25)$ \\
\hline & Renes polycystici $(\mathrm{N}, \%)$ & $3(18.75)$ \\
\hline \multicolumn{3}{|c|}{ Comorbidities } \\
\hline \multicolumn{2}{|c|}{ Hypertensio arterialis $(\mathrm{N}, \%)$} & $9(56.25)$ \\
\hline \multicolumn{2}{|r|}{ Cor hypertensivum compensatum (N, \%) } & $2(12.50)$ \\
\hline \multicolumn{2}{|c|}{ Cardiomyopathia dilatativa $(\mathrm{N}, \%)$} & $0(0.00)$ \\
\hline \multicolumn{2}{|c|}{ Diabetes mellitus complicatus (N, \%) } & $5(31.25)$ \\
\hline
\end{tabular}


The percentage of interdialysis yield in the patient's body weight ( $\%$ IDWG) was calculated using the formula: $\% \mathrm{IDWG}=[$ (body weight of the patient before dialysis $(\mathrm{kg})$ - "dry body weight" of the patient) $(\mathrm{kg}) /$ "dry body weight" of the patient)] x 100].

Dialysis adequacy was assessed based on the singlepool $\mathrm{Kt} / \mathrm{V}$ index calculated according to the Daugridas second-generation formula: $\mathrm{spKt} / \mathrm{V}=-\ln (\mathrm{C} 2 / \mathrm{C} 1-0.008 \mathrm{x}$ $\mathrm{T})+(4-3.5 \times \mathrm{C} 2 / \mathrm{C} 1) \times \mathrm{UF} / \mathrm{W}$, where: $\mathrm{C} 1$ - urea value before dialysis, $\mathrm{C} 2$ - urea value after dialysis ( $\mathrm{mmol} / \mathrm{L}), \mathrm{T}$ - hemodialysis duration (h), UF - interdialysis yield (L), $\mathrm{W}$ - body weight after hemodialysis $(\mathrm{kg})$. According to $\mathrm{K}$ / DOQI guidelines, hemodialysis is adequate if $\mathrm{spKt} / \mathrm{V} \geq$ 1.2 .

The degree of urea reduction - URR index was calculated using the following formula: $U R R=(1-R) x$ $100 \%$, where: $\mathrm{R}$ represents the ratio of serum urea concentration after and before dialysis treatment. Dialysis is adequate if the URR index $=65-70 \%$.

Blood flow through the vascular approach - Qavf was determined by Color Doppler ultrasound, on a Logic P5 instrument, using a $7.5 \mathrm{MHz}$ probe. Blood flow through the vascular approach that provides adequate hemodialysis is $500-1000 \mathrm{~mL} / \mathrm{min}$.

Kolmogorov-Smirnov test, Student's T test for bound samples and Wilcoxon test were used for statistical analysis of the obtained data. Significance thresholds were 0.05 and 0.01 , respectively.

\section{RESULTS}

A cross-sectional study was conducted at the Center for Nephrology and Dialysis of the Clinical Center Kragujevac, which included patients being treated with extended hemodialysis. The basic characteristics of the MCO membrane are shown in Table 1. Sixteen patients (12 men, 4 women), average age $60.38 \pm 9.81$ years, average length of hemodialysis treatment $3.97 \pm 3.6$ years, average nutrition $27.31 \pm 8.05 \mathrm{~kg} / \mathrm{m}^{2}$ and the average adequacy index of extended hemodialysis - spKt/V $1.25 \pm$ 0.30 . General data on patients are shown in Table 2.

For the treatment of anemia in the examined patients, short-acting and long-acting erythropoietins, intravenous iron preparation, i.v. vitamin B preparations and folic acid (per os) were used. The average monthly dose of short- acting erythropoietin was $32000.00 \pm 16589.15$ IU, longacting erythropoietin $192.50 \pm 108.99 \mu \mathrm{g}$, the average monthly dose of intravenous iron was $350.00 \pm 358.57$ $\mathrm{mg}$, the average monthly dose of iv vitamin $\mathrm{C}$ was $6,000.00 \pm 0.00 \mathrm{mg}$, the average monthly number of ampoules of Beviplex was $168.00 \pm 0.00$, the average monthly dose of vitamin $\mathrm{B}_{12}$ was $2500.00 \pm 0.00 \mu \mathrm{g}$, and the average monthly dose of folic acid was $159.38 \pm 37.50$ $\mathrm{mg}$. Secondary hyperparathyroidism in the examined patients was treated with calcium-containing phosphate binders, active metabolites of vitamin D and paricalcitol. The average monthly dose of rocaltrol was $2.50 \pm 0.71 \mu \mathrm{g}$. In accordance with medical indications, patients did not receive paricalcitol.

A combination of angiotensin I converting enzyme blockers, angiotensin II receptor blockers, beta blockers, calcium channel blockers and Henle's loop diuretics was used to treat arterial hypertension. Renin-angiotensin system blockers (mainly angiotensin I converter blockers) were used in $12(75.00 \%)$ patients, beta blockers in 7

Table 3. Average values of test parameters

\begin{tabular}{|l|c|}
\hline \multirow{2}{*}{ Variable* } & Statistical parameters \\
\cline { 2 - 2 } & Xsr \pm SD \\
\hline Hb $(\mathrm{g} / \mathrm{l})$ & $105.25 \pm 7.25$ \\
\hline $\mathrm{Hct}(\%)$ & $32.62 \pm 5.44$ \\
\hline $\mathrm{MCV}(\mathrm{fl})$ & $94.51 \pm 6.95$ \\
\hline $\mathrm{MCH}(\mathrm{pg})$ & $30.87 \pm 2.38$ \\
\hline $\mathrm{MCHC}(\mathrm{g} / \mathrm{l})$ & $326.38 \pm 5.40$ \\
\hline Fe $(\mu \mathrm{mol} / \mathrm{l})$ & $9.49 \pm 3.72$ \\
\hline TSAT $(\%)$ & $29.25 \pm 11.91$ \\
\hline FER $(\mathrm{ng} / \mathrm{ml})$ & $596.44 \pm 180.19$ \\
\hline $\mathrm{CRP}(\mathrm{mg} / \mathrm{l})$ & $9.44 \pm 3.14$ \\
\hline $\mathrm{UP}(\mathrm{g} / \mathrm{l})$ & $66.44 \pm 3.56$ \\
\hline ALB $(\mathrm{g} / \mathrm{l})$ & $37.38 \pm 1.59$ \\
\hline PALB $(\mathrm{g} / \mathrm{l})$ & $0.28 \pm 0.07$ \\
\hline TRSF $(\mathrm{g} / \mathrm{l})$ & $1.57 \pm 0.40$ \\
\hline $\mathrm{UA}(\mu \mathrm{mol} / \mathrm{l})$ & $371.06 \pm 64.80$ \\
\hline nPCR $(\mathrm{g} / \mathrm{kg} / 24 \mathrm{~h})$ & $1.90 \pm 0.54$ \\
\hline VitD $(\mathrm{ng} / \mathrm{ml})$ & $18.00 \pm 4.44$ \\
\hline iPTH $(\mathrm{pg} / \mathrm{ml})$ & $226.62 \pm 143.64$ \\
\hline RR- $\beta_{2} \mathrm{M}(\%)$ & $70.60 \pm 5.88$ \\
\hline RR-Alb $(\%)$ & $4.94 \pm 2.49$ \\
\hline
\end{tabular}

*see abbreviations

Table 4. Influence of a single session of expanded on serum albumin and $\beta_{2}$-microglobulin concentration

\begin{tabular}{|l|c|c|c|}
\hline \multirow{2}{*}{ Test parameters } & \multicolumn{2}{|c|}{ Value } & \multirow{2}{*}{ Significance $(\mathrm{p})$} \\
\cline { 2 - 3 } & Before HDx & After HDx & \\
\cline { 2 - 3 } & $\mathrm{Xsr} \pm \mathrm{SD}$ & $\mathrm{Xsr} \pm \mathrm{SD}$ & \\
\hline Albumin $(\mathrm{g} / \mathrm{L})$ & $37.38 \pm 1.59$ & $35.50 \pm 0.74$ & $\mathrm{z}_{\mathrm{emp}}=-3.575, \mathrm{p}<0.0001$ \\
\hline$\beta_{2}$-microglobulin $(\mathrm{mg} / \mathrm{L})$ & $29.85 \pm 5.24$ & $8.75 \pm 2.10$ & $\mathrm{t}_{\mathrm{emp}}=7.566, \mathrm{p}<0,0001$ \\
\hline
\end{tabular}

HDx - expanded hemodialysis 
(43.75\%) patients, in $7(43.75 \%)$ patients with Henle loop diuretics, and in 7 (43.75\%) patients with calcium channel blockers.

The average values of anemia, iron status, microinflammation, malnutrition, secondary hyperparathyroidism parameters of $\beta_{2}$-microglobulin reduction index and albumin reduction index are shown in Table 3.

Mean serum albumin and $\beta_{2}$-microglobulin values before and after a single extended hemodialysis session are shown in Table 4. All study patients had a serum albumin concentration greater than $35 \mathrm{~g} / \mathrm{L}(37.38 \pm 1.59$ $\mathrm{g} / \mathrm{L})$ prior to an extended hemodialysis session. After a single session of extended hemodialysis, the serum albumin concentration in all patients was higher than 35 $\mathrm{g} / \mathrm{L}(35.50 \pm 0.72 \mathrm{~g} / \mathrm{L})$. There is a highly statistically significant difference between serum albumin concentrations before and after a single session of extended hemodialysis $(p<0.01)$. The average decrease in albumin concentrations during a single session of extended hemodialysis was $1.88 \pm 1.02 \mathrm{~g} / \mathrm{L}$, and the albumin reduction index was $4.94 \pm 2.49 \%$.

Serum $\beta_{2}$-microglobulin concentration before a single session of extended hemodialysis less than $25 \mathrm{mg} / \mathrm{L}$ was found in one patient $(6.25 \%)$ and less than $30 \mathrm{mg} / \mathrm{L}$ in 10 $(62.50 \%)$ patients. In $6(37.50 \%)$ patients the serum $\beta_{2}$ microglobulin concentration was higher than $30 \mathrm{mg} / \mathrm{L}$. There is a highly statistically significant difference between serum $\beta_{2}$-microglobulin concentrations before and after a single session of extended hemodialysis $(\mathrm{p}<$ $0.01)$. The average decrease in $\beta 2$-microglobulin concentrations during a single session of extended hemodialysis was $21.10 \pm 4.35 \mathrm{mg} / \mathrm{L}$, while the average reduction index of $\beta_{2}$-microglobulin during a single session of extended hemodialysis was $70.60 \pm 5.88 \%$.

\section{DISCUSSION}

Cardiovascular diseases are the leading cause of death in patients treated with regular hemodialysis. Uremic toxins, microinflammation, malnutrition, oxidative stress, endothelial dysfunction, erythropoietin resistance and anemia are significant non-traditional risk factors for the development of cardiovascular disease (17-20). Early detection and optimal control of nontraditional risk factors play a key role in preventing the development of cardiovascular disease in this patient population $(21,22)$.

Beta-2-microglobulin is a medium molecular weight uremic toxin (MW - $11.8 \mathrm{kDa}$ ), soluble in water, and an increase in its serum concentration results in the development of dialysis-related amyloidosis - DRA (Dialysis-Related Amyloidosis) (23-25). In patients treated with regular hemodialysis, the serum $\beta_{2}$ microglobulin concentration before a single dialysis session should be $<30 \mathrm{mg} / \mathrm{L}(23-25)$.
In the examined patients, the concentration of $\beta_{2}$ microglobulin in the serum before a single session of extended hemodialysis less than $25 \mathrm{mg} / \mathrm{L}$ is present in one patient $(6.25 \%)$, less than $30 \mathrm{mg} / \mathrm{L}$ in $10(62.50 \%)$ patients, and in $6(37.50 \%)$ patients the serum $\beta_{2}$ microglobulin concentration was higher than $30 \mathrm{mg} / \mathrm{L}$. During a single session of extended hemodialysis, the average decrease in serum $\beta_{2}$-microglobulin concentration was $21.10 \pm 4.35 \mathrm{mg} / \mathrm{L}$, while the average reduction index of $\beta_{2}$-microglobulin during a single session of extended hemodialysis was $70.60 \pm 5.88 \%$.

The results of the research done so far have shown that during a single session of standard high-flux "high-flux" hemodialysis the reduction index for $\beta_{2}$-microglobulin is $50-60 \%$, in MCO hemodialysis ("medium cut-off" dialysis membrane) $70 \%$, and in high-volume (Vconv > 22 liters per session) postdilution online hemodiafiltration $80-85 \%$ $(R R \geq 80 \%)(23-27)$.

The reduction index of $\beta_{2}$-microglobulin achieved during a single session of extended hemodialysis with a Theranova $\AA 500$ dialyzer, at a blood flow rate of $\mathrm{Qb}=450$ $\pm 80 \mathrm{~mL} / \mathrm{min}$, is $74.70 \pm 8.09 \%(28-30)$. The lower extraction index of $\beta_{2}$-microglobulin in our examined patients $(70.60 \pm 5.88 \%)$ is a consequence of low blood flow - $\mathrm{Qb}=230.00 \pm 30.55 \mathrm{~mL} / \mathrm{min}$.

Extended hemodialysis effectively removes uremic toxins of medium molecular weight, primarily due to the diffusion process, but also due to high internal filtration in the dialyzer, without significant loss of albumin (28-30). In addition to the strength of blood flow $-\mathrm{Qb}$ (diffusion process), the index of $\beta_{2}$-microglobulin reduction in patients treated with MCO hemodialysis also depends on the characteristics of the dialyzer (internal filtration process).

Internal filtration provides high convective transport (convective flow), which contributes to the high clearance of medium molecular weight uremic toxins. For blood flow rate $-\mathrm{Qb}=300 \mathrm{~mL} / \mathrm{min}$, dialysate flow rate $-\mathrm{Qd}=$ $500 \mathrm{~mL} / \mathrm{min}$ and net ultrafiltration flow rate - Qnuf $=0$ $\mathrm{mL} / \mathrm{min}$, internal filtration with Theranova ${ }^{\circledR} 400$ dialyzer is $30 \mathrm{~mL} / \mathrm{min}$, and with dialyzer Theranova ${ }^{\circledR} 50040$ $\mathrm{mL} / \mathrm{min}$. At flow rate $-\mathrm{Qb}=400 \mathrm{~mL} / \mathrm{min}$, dialysate flow rate $-\mathrm{Qd}=500 \mathrm{~mL} / \mathrm{min}$ and net ultrafiltration flow rate Qnuf $=0 \mathrm{~mL} / \mathrm{min}$, internal filtration at Theranova ${ }^{\circledR} 400$ dialyzer is $40 \mathrm{~mL} / \mathrm{min}$, and for dialyzer Theranova ${ }^{\circledR} 500$ $50 \mathrm{~mL} / \mathrm{min}$. When the flow rate of net ultrafiltration is Qnuf $=0 \mathrm{~mL} / \mathrm{min}$, the internal filtration is by definition equal to the return filtration. When the flow rate of net ultrafiltration - Qnuf increases, the internal filtration also increases.

For the Theranova ${ }^{\circledR} 400$ dialyzer, for the net ultrafiltration flow rate - Qnuf $=16 \mathrm{~mL} / \mathrm{min}$, the internal filtration is $56 \mathrm{~mL} / \mathrm{min}$, while the return filtration is 40 $\mathrm{mL} / \mathrm{min}$. With the Theranova ${ }^{\circledR} 500$ dialyzer, the internal 
filtration is increased to $66 \mathrm{~mL} / \mathrm{min}$, and the return filtration remains at $50 \mathrm{~mL} / \mathrm{min}$. The $\mathrm{MCO}$ membrane provides significant ultrafiltration by the interaction (combination) between the hydraulic permeability of the membrane and the reduced inner diameter of the capillary fibers (the inner diameter is less than $200 \mu \mathrm{m}$ ).

For Theranova ${ }^{\circledR} 400$ and Theranova ${ }^{\circledR} 500$ dialyzers, the inner diameter of the capillary fibers is $180 \mu \mathrm{m}$. High internal filtration, combined with increased screening capacity of MCO membranes, leads to an increase in the clearance of middle molecular weight uremic toxins. Internal filtration increases in proportion to blood flow rate $(\mathrm{Qb})$ and $\mathrm{MCO}$ hemodialysis membrane surface (2830). Compared to standard hemodialysis with "high-flux" dialysis membranes, hemodialysis with MCO membranes provides high clearance of middle molecular weight uremic toxins, while preventing significant albumin loss (31). The results of the research done so far have shown that during a single session of extended hemodialysis with MCO membrane, 1.20-3.90 g per session is lost (31). In the examined patients, at the average strength of blood flow $-\mathrm{Qb}=230.00 \pm 30.55 \mathrm{~mL} / \mathrm{min}$ and the average strength of net ultrafiltration - Qnuf $=750.00 \pm 223.60$ $\mathrm{mL} / \mathrm{h}$, the average decrease in albumin concentration during a single session extended hemodialysis was $1.88 \pm$ $1.02 \mathrm{~g} / \mathrm{L}$, and the average albumin reduction index was $4.94 \pm 2.49 \%$. The results of this study are in agreement with other authors who showed that the albumin reduction index $-\mathrm{RR}-\mathrm{Alb}<11 \%$ indicated the loss of albumin by dialysate in the amount of $<3.5 \mathrm{~g} / 4 \mathrm{~h}$ (32). After a single session of extended hemodialysis, the serum albumin concentration in all patients was higher than $35 \mathrm{~g} / \mathrm{L}$ (35.50 $\pm 0.72 \mathrm{~g} / \mathrm{L})$. During an extended hemodialysis session, less than $4.0 \mathrm{~g}$ of albumin $(\leq 4.0 \mathrm{~g} / 4 \mathrm{~h})$ is lost, which is of great importance in order to prevent the development of malnutrition (33). Microinflammation and increased serum leptin concentrations of patients treated with regular dialysis play a significant role in the development of malnutrition. Leptin is a middle molecular weight adipokin $(\mathrm{MW}-17 \mathrm{kDa}$ ), which reduces the appetite of patients treated with regular dialysis (energy intake $<30$ $\mathrm{kcal} / \mathrm{kg} /$ day, protein intake less than $0.8 \mathrm{~g} / \mathrm{kg} /$ day). Body mass index - BMI $<20 \mathrm{~kg} / \mathrm{m}^{2}$, serum albumin concentration $<35 \mathrm{~g} / \mathrm{L}$, serum prealbumin concentration less than $0.30 \mathrm{~g} / \mathrm{L}$ and normalized protein degradation rate $-\mathrm{nPCR}>1.0 \mathrm{~g} / \mathrm{kg} /$ day are factors risk of adverse outcome in patients treated with regular dialysis (33). Studies show that extended hemodialysis effectively removes proinflammatory cytokines and leptin, reduces microinflammation, reduces serum leptin concentrations, prevents the development of malnutrition, and improves the outcome of these patients $(33,34)$.

Uremic toxins encourage the development of microinflammation in patients treated with regular dialysis. Pro-inflammatory cytokines (interleukin-6) stimulate hepcidin synthesis in liver cells. Hepcidin is a middle molecular weight uremic toxin ( $\mathrm{MW}-2.7 \mathrm{kDa})$, which blocks the release of iron from cells of the reticuloendothelial system. This results in the development of functional iron deficiency, resistance to the action of erythropoietin and the development of anemia. Extended hemodialysis reduces microinflammation, effectively removes hepcidin, reduces resistance to the action of erythropoietin and enables optimal control of anemia (achieving and maintaining the target value of hemoglobin in the blood of patients treated with regular dialysis) $(34,35)$.

In conclusion, extended hemodialysis, diffusion and internal filtration processes, effectively removes uremic toxins of middle molecular weight in the range of 0.5-50 $\mathrm{kDa}$, reduces microinflammation, oxidative stress, malnutrition, resistance to erythropoietin, prevents the development of amyloidosis associated with dialysis, prevents the development of acceleration and improves the outcome of patients treated with regular dialysis.

\section{ACKNOWLEDGMENTS}

Authors would like to express their deepest gratitude to the Ministry of Education, Science and Technological Development of the Republic of Serbia for the Grant $\mathrm{N}^{0} 175014$ and also to the Faculty of Medical Sciences University of Kragujevac for their Junior Project grants $\mathrm{N}^{0} 02 / 19$ and $\mathrm{N}^{0} 22 / 20$ from which the funds were used as the sources to financially support this paper.

\section{ABBREVIATIONS}

ALB - serum albumin concentration

CRP - serum C-reactive protein concentration

$\mathrm{Fe}$ - serum iron concentration

FER - serum ferritin concentration

$\mathrm{Hb}$ - hemoglobin

Hct - hematocrit

iPTH - serum intact parathyroid hormone concentration

$\mathrm{MCH}$ - mean corpuscular hemoglobin

$\mathrm{MCHC}$ - mean corpuscular hemoglobin concentration

$\mathrm{MCV}$ - mean corpuscular volume

$\mathrm{nPCR}$ - normalized protein degradation

PALB - serum prealbumin concentration

RR - Reduction Ratio ( $\beta_{2}$-microglobulin, albumin)

TRSF - serum transferrin concentration

TSAT - iron transferrin saturation

UA - serum uric acid concentration

UP - serum total protein concentration

VitD - serum vitamin D concentration 


\section{REFERENCES}

1. Cozzolino M, Mangano M, Stucchi A, Ciceri P, Conte F, Galassi A. Cardiovascular disease in dialysis patients. Nephrol Dial Transplant 2018; 33: 28-34.

2. Ahmadmehrabi S, Tang WHW. Hemodialysis-induced cardiovascular disease. Semin Dial 2018; 31: 258-67.

3. Wolley MJ, Hutchison CA. Large uremic toxins: an unsolved problem in end-stage kidney disease. Nephrol Dial Transplant 2018; 33(Suppl 3): 6-11.

4. Kaesler N, Babler A, Floege J, Kramann R. Cardiac remodeling in chronic kidney disease. Toxins 2020; 12: 161 .

5. Lekawanvijit S. Cardiotoxicity of uremic toxins: a driver of cardiorenal syndrome. Toxins 2018; 10: 352.

6. Velasquez MT, Centron P, Barrows I, Dwivedi R, Raj DS. Gut microbiota and cardiovascular uremic toxicities. Toxins 2018; 10: 287.

7. Mair RD. Sirich TL, Meyer TW. Uremic toxin clearance and cardiovascular toxicities. Toxins 2018; 10: 226.

8. Fujii H, Goto S, Fukagawa M. Role of uremic toxins for kidney, cardiovascular, and bone dysfunction. Toxins 2018; 10: 202

9. Dias GF, Bonan NB, Steiner TM, et al. Indoxyl sulfate, a uremic toxin, stimulates reactive oxygen species production and erythrocyte cell death supposedly by an organic anion transporter 2 (OAT2) and NADPH oxidase activity-dependent pathways. Toxins 2018; 10: 280.

10. Sahathevan S, Khor BH, Ng HM, et al. Understanding development of malnutrition in hemodialysis patients: a narrative review. Nutrients 2020; 12: 3147.

11. Ronco C, Clark WR. Haemodialysis membranes. Nat Rev Nephrol 2018; 14: 394-410.

12. Haroon S, Davenport A. Choosing a dialyzer: what clinicians need to know. Hemodialysis Int 2018; 22(Suppl 2): 65-74.

13. Wolley M, Jardine M, Hutchison CA. Exploring the clinical relevance of providing increased removal of large middle molecules. Clin J Am Soc Nephrol 2018; 13: $805-14$

14. Masacane I, Sakurai K. Current approaches to middle molecule removal: room for innovation. Nephrol Dial Transplant 2018; 33(Suppl 3): 12-21.

15. Tattersal JE, Ward RA. Online haemodiafiltration: definition, dose quantification and safety revisited. Nephrol Dial Transplant 2013; 28: 542-50.

16. Chapdelaine I, De Roij van Zuijewijn CLM, Mostovaya IM, et al. Optimization of the convection volume in online post-dilution haemodiafiltration: practical and technical issues. Clin Kidney J 2015; 8: 191-8.
17. Jaćović S, Jovanović M, Hamzagić N, Pavlović R, Petrović D. Erythropoietin resistance in hemodialysis patients. Acta Fac Med Naiss 2019; 36: 5-14.

18. Liakopoulos V, Roumeliotis S, Gorny X, Dounousi E, Mertens PR. Oxidative stress in hemodialysis patients: a review of the literature. Oxidative Med Cell Long 2017; 2017: 3081856.

19. Antić S, Draginić N, Nikolić T, Jeremić N, Petrović D. Oxidative stress in hemodialysis patients: pathophysiological mechanisms, clinical consequence and basic principles of treatment. Ser J Exp Clin Res 2019. (doi: 10.2478/sjecr-2019-0008).

20. Antić S, Draginić N, Jovanović M, et al. The relation between oxidative stress and carotid artery atherosclerosis in hemodialysis patients. Ser J Exp Clin Res 2019. (doi: 10.2478/sjecr-2019-0052).

21. Liakopoulos V, Roumeliotis S, Bozikas A, et al. (2019). Antioxidant supplementation in renal replacement therapy patients: is there evidence? Oxidative Med Cell Long 2019: 9109473.

22. Antić S, Draginić N, Pilčević D, et al. The influence of vitamin $\mathrm{E}$ coated dialysis membrane on oxidative stress during the single session of on-line hemodiafiltration. Vojnosanit Pregl 2019. (doi: 10.2298/VSP190730097A).

23. De Roij van Zuijdewijn CLM, Chapdelaine I, Nube $\mathrm{MJ}$, et al. Achieving high concentration volumes in postdilution online hemodiafiltration: a prospective multicenter study. Clin Kidney J 2017; 10: 804-12.

24. Marcelli D, Scholz C, Ponce P, et al. High-volume postdilution hemodiafiltration is a feasible option in rutine clinical practice. Artif Organs 2015; 39: 142-9.

25. Masacane I, Sakurai K. Current approaches to middle molecule removal: room for innovation. Nephrol Dial Transplant 2018; 33(Suppl 3): 12-21.

26. Mostovaya IM, Grooteman MPC, Basile C, et al.; on behalf of the EuDial group. High convection volume on online post-dilution haemodiafiltration: relevance, safety and costs. Clin Kidney J 2015; 8: 368-73.

27. Canaud B, Barbieri C, Marcelli D, et al. Optimal convection volume for improving patient outcomes in an international incident dialysis cohort treated with online hemodiafiltration. Kidney Int 2015; 88: 110816.

28. Lorenzin A, Neri M, Lupi A, et al. Quantification of internal filtration in hollow fiber hemodialyzers with medium cut-off membrane. Blood Purif 2018; 46: 196204.

29. Ronco C, Marchionna N, Brendolan A, Neri M, Lorenzin A, Rueda AJM. Expanded haemodialysis: from operational mechanism to clinical results. Nephrol Dial Transplant 2018; 33(Suppl 3): 41-7. 
30. Garcia-Prieto A, Vega A, Linares T, et al. Evaluation of the efficacy of a medium cut-off dialyser and comparison with other high-flux dialysers in konventional haemodialysis and online haemodiafiltration. Clin Kidney J 2018; 11: 742-6.

31. Cozzolino M, Maganoli L, Ciceri P, Conte F, Galassi A. Effects of a medium cut-off (Theranova ${ }^{\circledR}$ ) dialyser on haemodialysis patients: a prospective, cross-over study. Clin Kidney J 2019; 14: 382-9.

32. Maduell F, Rodas L, Broseta JJ, et al. Medium cut-off dialyzer versus eight hemodiafiltration dialyzers: comparison using a global removal score. Blood Purif 2019; 48: 167-74.
33. Sahathevan S, Khor BH, Ng HM, et al. Understanding development of malnutrition in hemodialysis patients: a narrative review. Nutrients 2020; 12: 3147.

34. Zickler D, Schindler R, Willy K, et al. Medium CutOff (MCO) membranes reduce inflammation in chronic dialysis patients-a randomized controlled clinical trial. PLOS One 2017; 12: e0169024.

35. Lim JH, Jeon Y, Yook JM, et al. Medium cut-off dialyzer improves erythropoiesis stimulating agent resistance in a hepcidin-independent manner in maintenance hemodialysis patients: results from a randomized controlled trial. Rep Sci 2020; 10: 16062. 